\title{
Lazarević-Lasègue sign
}

\author{
Sinal de Lazarević-Lasègue \\ Péricles Maranhão-Filho', Maurice Vincent²
}

\begin{abstract}
Charles Lasègue is reputed to have described the test/sign bearing his name, but he never wrote about it and misinterpreted its mechanism. The purpose of this note is to highlight the work of the Serbian, Laza Lazarević, who was first to present the original report of this seminal sign in sciatica and provide its appropriate pathophysiological interpretation.
\end{abstract}

Keywords: Lasègue’s sign; Lazarević's sign; sciatica.

\section{RESUMO}

Charles Lasègue guarda a reputação de ter descrito o sinal que leva seu nome, mas nunca escreveu sobre isso e interpretava erradamente sua etiopatogenia. O propósito desta nota é chamar atenção para o trabalho do sérvio Laza Lazarević, que apresentou a descrição original do sinal mais importante na ciatalgia e forneceu a interpretação apropriada da sua fisiopatologia.

Palavras-chave: Sinal de Lasègue; sinal de Lazarević; ciática.

\section{ERNEST-CHARLES LASĖGUE}

Ernest-Charles Lasègue (5 September,1816 - 20 March,1883) (Figure 1) was a French physician, epidemiologist, internist, neurologist, and psychiatrist at the Hôpital Pitié-Salpêtrière in Paris ${ }^{1,23}$.

The young Lasègue showed an extraordinary intelligence, although he was considered an irremediable student. He was interested in philosophy and rhetoric, spoke fluent Latin, and translated Greek texts. He received his doctoral degree in 1846. After obtaining his agrégation in 1853, he prospered and became one of the most brilliant physicians of the $19^{\text {th }}$ century, known as "the universal specialist".

Lasègue wrote about vertigo, epilepsy, general paralysis, catalepsy, migraine and onanism, among other subjects, publishing a total of 115 articles. In 1876, he was elected member of the Academy of Medicine. He passed away at the age of 66 from diabetes.

Lasègue has traditionally been considered the mastermind behind the test that bears his name. In the wards of l'Hôpital de la Pitié-Salpêtrière, he would perform the straight leg raise test routinely, emphasizing to his pupils its diagnostic significance as a sign constantly present in sciatica. However, Lasègue never published a word about this sign ${ }^{3}$. The description was given to him by his pupil J.J. Forst, in his doctoral thesis Contribuition a l'êtude Clinique de la Sciatique. Thèse pour le Doctorat en

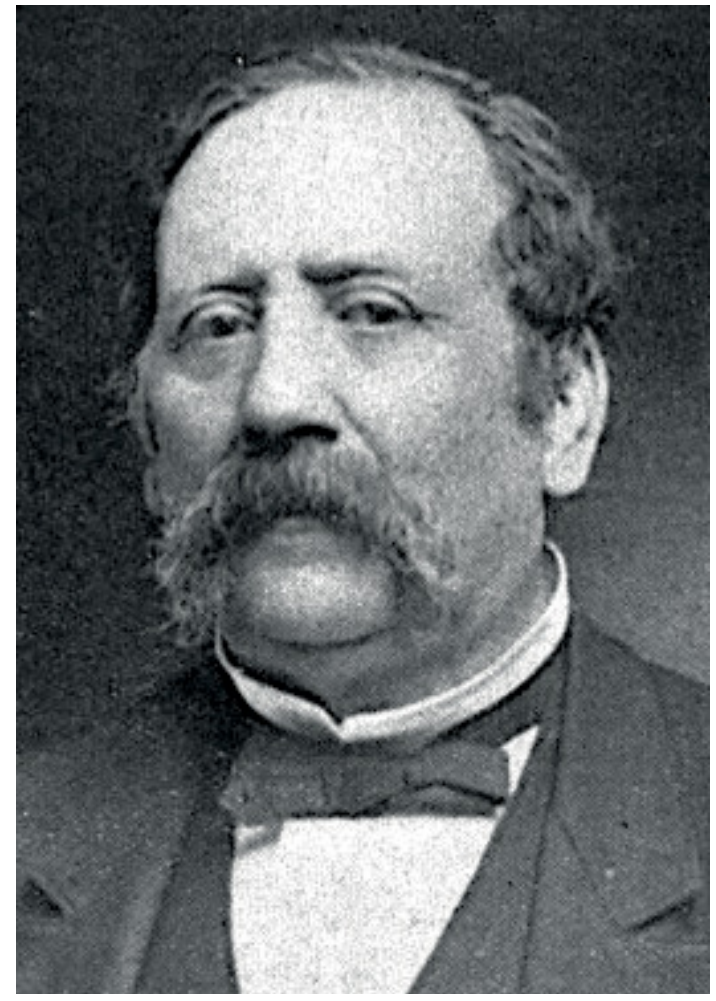

Source: http://psychiatrie.histoire.free.fr/pers/bio/lasegue.htm Figure 1. Ernest-Charles Lasègue.

${ }^{1}$ Universidade Federal do Rio de Janeiro, Hospital Universitário Clementino Fraga Filho, Departamento de Clínica Médica, Serviço de Neurologia, Rio de Janeiro RJ, Brasil;

${ }^{2}$ Neuroscience Research, Eli Lilly and Company, Indianapolis, USA.

Correspondence: Péricles Maranhão-Filho;Av. Prefeito Dulcídio Cardoso 1680/1802; 22620-311 Rio de Janeiro RJ, Brasil; E-mail:pmaranhaofilho@gmail.com 
Médecine, Paris; Faculté de Médecine de Paris, 18815. This work clearly explains the examination technique. The patient lies in the supine position, and the involved lower extremity is raised with the knee extended. The maneuver is repeated, with the leg flexed on the knee while the thigh is flexed on the pelvis (Figure 2A and B). The sign is present if the first maneuver evokes sciatic pain and the second does not.

Robert Wartenberg, one of the most vehement critics of the untruthful authorship of medical articles, wrote in 1941: "Since Lasègue described this phenomenon in 1861, many modifications of his maneuver have been introduced". Remarkably, he later lurched to the contrary, considering that "it is highly embarrassing to state the plain fact that all authors who quoted Lasègue's article of 1864 as a source of Lasègue's sign did not read the article".

Some authors believe that a possible source of the uncertainty concerning Lasègue and the famous sciatica sign is his article entitled Considérations sur la Sciatique, published in Archives Générales de Médecine (1864) ${ }^{7}$. Since this piece became a classic, it was natural that all and sundry would promptly assume, without questioning, that Lasègue discovered this renowned sign.

Forst and Lasègue mistakenly concluded that the sharp pain produced by raising the involved lower extremity with the knee extended was due to muscle mass compression of the sciatic nerve.

" $\ldots$ the sensation of pulling is very probably due to compression of the sciatic nerve by muscular contraction. ...We consider this sign to be pathognomonic of sciatica, for we have not found it in any other affliction of that region."

\section{LAZAR K. LAZAREVIĆ}

Lazar K. Lazarević (13 May,1851 - 10 January,1891) was born in Šabac, a city in the administrative center of the Mačva District, western Serbia.
Lazarević (Figure 3) was a physician, scientist, writer, and translator in the field of Neurology. After completing high school in 1867, he entered law school, during which time he realized Medicine was his true passion ${ }^{8}$. He traveled to Berlin in 1872 to study Medicine but returned to Serbia during the Serbian-Turkish war (1876-1877) and was awarded the medal of devotion to service9. He returned to Berlin after the war to continue his education, obtained his $\mathrm{PhD}$, and eventually came back to Serbia.

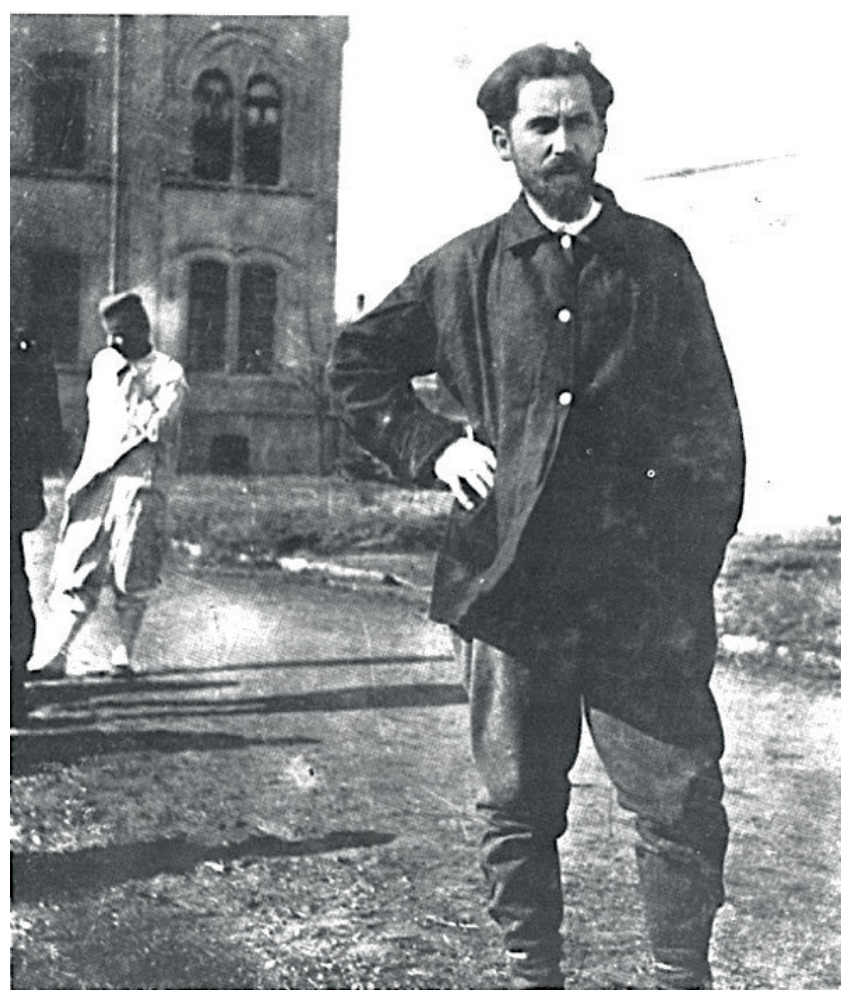

Source: http://wannabemagazine.com/srecan-rodendan-laza-lazarevic/ Figure 3. Lazar K. Lazarević.
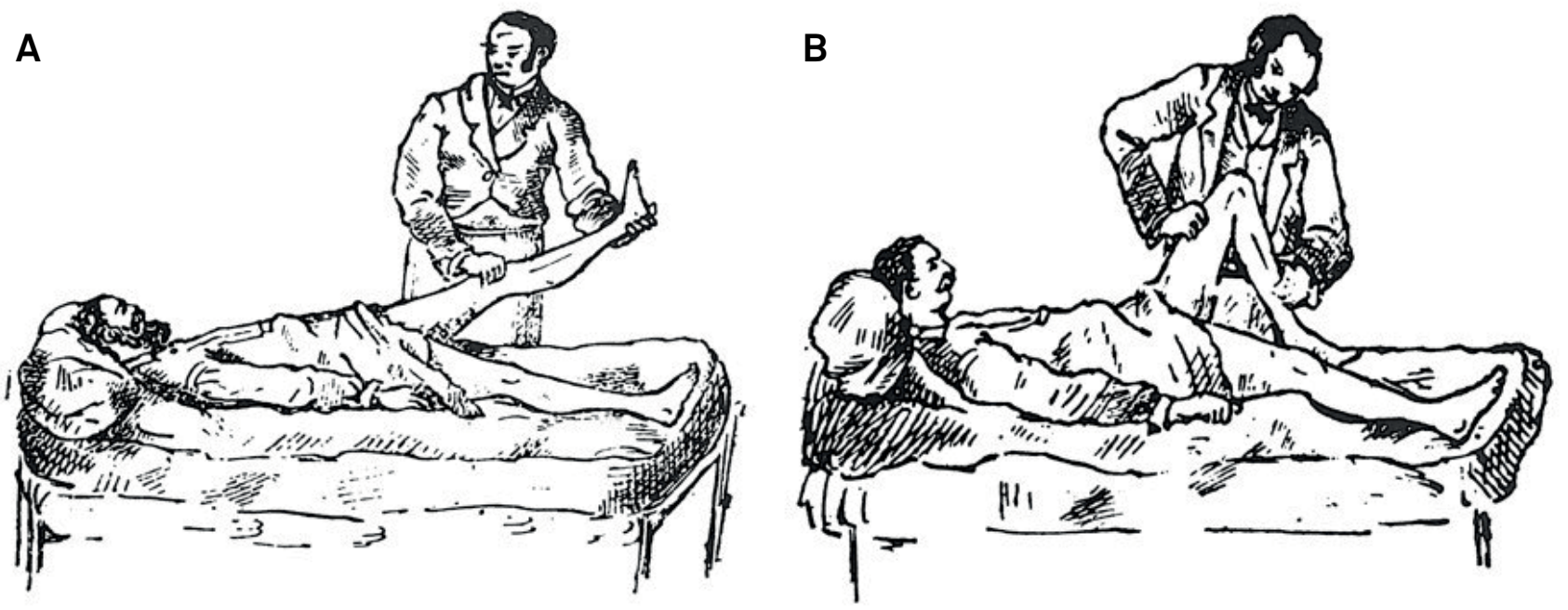

Figure 2. First maneuver; elevation with straight leg (A). Second maneuver, the control test. The leg is flexed on the thigh (B) ${ }^{5}$. 
He dedicated his short professional life (11 years of medical and literary work from 1879 to 1890), to reforming Serbian Medicine and became one of the most distinguished medical scientists of his time. Lazarević published 72 articles in national and international journals, many of them about neurological diseases.

In the article Ischiac postica cotunnii: one contribution to its differential diagnosis, first published in Serbian in the Serbian Archives of Medicine in 1880, and republished in German in 1884, based on six patients from his medical practice, Lazarević correctly considered that stretching the sciatic nerve was the cause of pain during the straight leg raising test. He died prematurely from tuberculosis in $1891^{9}$.

In 1884, based on experiments on a cadaver, Lucien de Beurmann elegantly suggested that the real cause of the famous signal is the stretching of the sciatic nerve itself rather than a sciatic muscular compression ${ }^{10}$. He exposed the trunk of the sciatic nerve on the posterior aspect of the thigh between the biceps femorus and semitendinosus muscles. Part of the nerve was resected and replaced by a rubber tube of the same length. He observed that, on performing the straight leg raise, the length of the rubber tube increased from $11 \mathrm{~cm}$ to $18 \mathrm{~cm}$ by maximal flexion of the straight leg toward the pelvis. Modern neuroimaging suggests that displacement of the medulla and conus medullaris can play a role in this sign ${ }^{11}$. Apart from the pure mechanical effect, sensitization at the dorsal root ganglion and posterior horn secondary to the nerve compression lowers the pain threshold ${ }^{12}$.

Since the original publication in 1880, several modifications of the classic maneuver have been introduced to improve the test performance, including additional dorsiflexion, supination of the foot, dorsiflexion of the big toe, and adduction with inward rotation of the $\operatorname{leg}^{6}$. A false sign frequently observed in malingerers may be detected by having the patient lying prone with the affected leg close and parallel to the edge of the bed. If the leg drops, there is stretching of the sciatic nerve and consequent pain, which is absent in the faux cases ${ }^{2}$. The crossed straight leg raising test may be more reliable for disc protrusion as it indicates more severe compression and centrally located prolapse ${ }^{13}$.

The Lazarević-Lasègue sign, also known as the Lasègue test, Lazarević's sign, or straight leg raise test, has been used extensively in the evaluation of patients with sciatica. Next to the Babinski and Romberg signs, the Lazarević-Lasègue remains one of the most popular and relevant signs in Neurology ${ }^{1}$.

\section{References}

\footnotetext{
1. Wartenberg R. On neurologic terminology, eponyms and the Lasègue sign. Neurology, 1956;6(12):853-8. https://doi.org/10.1212/WNL.6.12.853

2. Wartenberg R. Diagnostic test in neurology. Chicago: Year Book Publishers; 1954.

3. Wartenberg R. Lasègue's sign and Kernig sign. Arch Neurol Psychiat. 1951;66:58-61.

4. Halabe CM, Prensky MB, Fastilcht EB. Charles Ernest Lasègue. Acta Ortop Mex. 2008;22(5):341-2.

5. Forst JJ. Contribution à l'ètude clinique de la sciatique thèse de médecine de Paris. Paris: A. Parent; 1881.

6. Wartenberg R. Stretching test in neuritis. Cal West Med. 1941;55(2):76-9.

7. Lasègue C.Considérations sur la sciatique. Arch Gen Med. 1864;6(4):558-80

8. Gavrilovic A. Laza Lazarević (1851-1891). 2018 [acess 2018 feb 22]. Available from: http://riznicasrpska.net/knjizevnost/index. php?topic $=319.0$
}

9. Draca S, Lazar K. Lazarević, the author who first described the straight leg raising test. Neurology. 2015;85(2):1074-7. https://doi.org/10.1212/WNL.0000000000001958.

10. De Beurmann L. Note sur un signe peu connu de la sciatique: recherches experimentales. Arch Physiol Norm Pathol. 1884;16:375-80.

11. Rade M, Könönen M, Marttila J, Shacklock M, Vanninen R, Kankaanpää $M$ et al. In vivo MRI measurement of spinal cord displacement in the thoracolumbar region of asymptomatic subjects with unilateral and sham straight leg raise tests. PLoS One. 2016;11(6):e0155927. https://doi.org/10.1371/journal.pone.0155927

12. Benarroch EE. Central neuron-glia interactions and neuropathic pain. Overview of recent concepts and clinical implications. Neurology. 2010;75(3):273-8. https://doi.org/10.1212/WNL.0b013e3181e8e984

13. Kamath SU, Kamath SS. Lasègue's sign.J Clin Diagn Res. 2017;11(5):RG01-2. https://doi.org/10.7860/JCDR/2017/24899.9794 